\title{
Permian stratigraphy and palynology of the Lower Karoo Group in Mozambique - a 2020 perspective
}

\author{
Gilda Lopes ${ }^{1 *}$, Zélia Pereira², Paulo Fernandes ${ }^{1}$, João Marques ${ }^{3}$, \\ Márcia Mendes ${ }^{4}$ and Annette E. Götz ${ }^{5}$
}

With 5 figures

\begin{abstract}
In the past decade, the increase in the number of palynological works in Mozambique documents the significance of palynology in dating the late Palaeozoic basins in this region of southwestern Gondwana. The new information gained mainly from the study of the Moatize-Minjova Coal Basin is the basis for a better understanding of the regional biostratigraphy, as well as of palaeoenvironmental and palaeoclimatic conditions during the Permian. Here we provide a review on the Permian palynostratigraphy and its implications for lithostratigraphic correlation of Lower Karoo basins in Mozambique. The new biostratigraphic information leads to the conclusion that an age update for the lithostratigraphic units established for the Lower Karoo in Mozambique (Vúzi, Moatize, and Matinde formations) is most needed. The Cisuralian palynological association in Mozambique is characterized by long-range taxa recorded since the middle Cisuralian (Sakmarian to Artinskian) (Alisporites spp., Cannanoropollis spp., Horriditriletes spp., Laevigatosporites spp., Potonieisporites spp., Protohaploxypinus spp.). Several first occurrences are also recorded in the late Cisuralian (Kungurian) (e.g., Cirratriradites africanensis, Marsupipollenites triradiatus, and Vittatina spp.). The Guadalupian association is mainly characterized by taxa that extend their range since the Cisuralian (e.g., Alisporites spp., Cirratriradites africanensis, Guttulapollenites hannonicus, Horriditriletes ramosus, Kraeuselisporites enormis, Lueckisporites virkkiae, Limitisporites monstruosus, Marsupipollenites striatus, M. triradiatus, Pakhapites fusus, Platysaccus papilionis, Thymospora pseudothiessenii, and Weylandites lucifer), with only few first occurrences (Lueckisporites virkkiae, Striatopodocarpites cancellatus, and S. fusus) and last occurrences (Cirratriradites africanensis, Limitisporites monstruosos) being recorded. The Lopingian palynological association includes most of the taxa described for the Guadalupian. In contrast, Corisaccites alutas, Indotriradites niger, Klausipollenites schaubergeri, Lunatisporites pellucidus, Osmundacidites senectus, Polypodiisporites spp., P. mutabilis, and Protohaploxypinus microcorpus are recorded for the first time. Indication of the proximity to the Permian-Triassic Boundary is supported by the occurrence of Klausipollenites schaubergeri, Protohaploxypinus microcorpus, and Osmundacidites senectus in the upper part of the Matinde Formation. Based on the palynological data, the oldest rock unit, the Vúzi Formation, was deposited in the Permian (middle Cisuralian), and no older sedimentary rocks are currently known for the Lower Karoo Group in Mozambique. The palynological associations described also indicate that the
\end{abstract}

\footnotetext{
Authors' addresses:

1 CIMA - Centre for Marine and Environmental Research, Universidade do Algarve, Campus de Gambelas, 8005-139 Faro, Portugal.gmlopes@ualg.pt; pfernandes@ualg.pt

2 Laboratório Nacional de Energia e Geologia (LNEG), Rua da Amieira, Apartado 1089, 4466-901 S. Mamede Infesta, Portugal. zelia.pereira@lneg.pt

${ }^{3}$ Gondwana Empreendimentos e Consultorias, Limitada, Rua B, no. 233, Bairro da COOP, Caixa Postal 832, Maputo, Mozambique. joaomarques@gondwana.co.mz

${ }^{4}$ Laboratório Nacional de Energia e Geologia (LNEG), Bairro da Val d'Oca. Apartado p. 14, 7601-909 Aljustrel, Portugal. marcia.mendes@lneg.pt

5 State Authority for Mining, Energy and Geology, 30655 Hannover, Germany. annette.goetz@lbeg.niedersachsen.de

* Corresponding author: gmlopes@ualg.pt
} 